\title{
Emerging Role of IL-17 in Atherosclerosis
}

\author{
Shuang Chen Timothy R. Crother Moshe Arditi \\ Division of Pediatric Infectious Diseases and Immunology, Burns and Allen Research Institute, Cedars-Sinai \\ Medical Center and David Geffen School of Medicine at UCLA, Los Angeles, Calif., USA
}

\section{Key Words}

Atherosclerosis $\cdot \mathrm{IL}-17 \cdot$ Innate and adaptive immunity

\begin{abstract}
The IL-23-IL-17 axis is emerging as a critical regulatory system that bridges the innate and adaptive arms of the immune system. Th17 cells have been linked to the pathogenesis of several chronic inflammatory and autoimmune diseases. However, the role of Th17 cells and IL-17 in various stages of atherogenesis remains poorly understood and is only beginning to be elucidated. While IL-17 is a predominantly proinflammatory cytokine, it has a pleiotropic function and it has been implicated both as an instigator in the pathogenesis of several inflammatory disorders as well as being protective in certain inflammatory disease models. Therefore, it is not surprising that the current literature is conflicting on the role of IL-17 during atherosclerotic lesion development. Various approaches have been used by several groups to discern the involvement of IL-17 in atherosclerosis. While one study found that IL-17 is protective against atherosclerosis, several other recent studies have suggested that IL-17 plays a proatherogenic role. Thus, the function of IL-17 remains controversial and awaits more direct studies to address the issue. In this review, we will highlight all the latest studies involving IL-17 and atherosclerosis, including both clinical and experimental research.

Copyright $\odot 2010$ S. Karger AG, Basel
\end{abstract}

\section{Introduction}

Atherosclerosis is a lipid-driven, chronic inflammatory disease of the vessel wall in which both innate and adaptive immune responses play a role [1]. Immune cells and their mediators directly cause the chronic arterial inflammation that is a hallmark of atherosclerosis. Macrophages, T lymphocytes and, to a lesser extent, mast cells contribute to the smoldering inflammatory response in the vessel wall $[2,3]$. The array of cytokines implicated in atherosclerosis are strikingly similar to those used by immune effector cells to kill foreign pathogens and defective or diseased host cells [4]. Virtually every major cell lineage used in host defense has been identified in human and/or animal plaques [4-6].

Numerous genetic loss- or gain-of-function studies in animal models and other evidence shows that immune cell types are generally neither bystanders nor a consequence of plaque development, but instead directly participate in the disease. T cells are known to play a critical role during lesion development. Both Th1 and Th2 cells are involved in the process in a delicate interplay between the two cell types [7]. The recent addition of T helper 17 (Th17) cells to the mix has further complicated the roles each cell type might play during lesion development. The IL-23 (interleukin-23)-IL-17 axis is emerging as a critical regulatory system that bridges the innate and adaptive

\section{KARGER}

(C) 2010 S. Karger AG, Basel

Fax +41613061234

E-Mail karger@karger.ch

www.karger.com
Prof. Dr. Moshe Arditi

Department of Pediatrics, Cedars-Sinai Medical Center

North Tower, 8700 Beverly Blvd.

Los Angeles, CA 90048 (USA)

Tel. +1 310423 4471, Fax +1 818784 2582,E-Mail moshe.arditi@cshs.org 
immune systems. While IL-17 is predominantly a proinflammatory cytokine, it has pleiotropic and environment-specific functions. Indeed IL-17 was found to be both proinflammatory and protective for various inflammatory disease models, depending on the model and the environment it acts in [8-10].

While IL-17 has been reported to be important in the pathogenesis of several inflammatory disorders and has been linked to inflammatory bowel disease [11-13], others have reported that IL-17A mediates a protective effect on T cell-driven intestinal inflammation in vivo [8]. Since the Th1 axis plays a critical role in the development of atherosclerosis, and because the Th17 pathway can drive Th1 responses, one would expect that IL-17 would have a proatherogenic function. However, IL-17 has complex and multiple functions, including regulatory functions, and the role of IL-17A in atherogenesis remains unclear. Recently, several papers have shown conflicting data: one study suggested a protective function for IL-17 in atherogenesis [14], while several others showed a proatherogenic properties of IL-17 and Th17 T-cells [15, 16]. Here we summarize the current understanding of $\mathrm{T}$ lymphocytes, particularly Th17 cells in the development of atherosclerosis.

\section{Progression of Atherogenesis}

The earliest sign of atherosclerosis is endothelial cell dysfunction, activation in response to oxidized lipids in the subendothelium, and expression of VCAM-1 (vascular cell-adhesion molecule 1) [17, 18], which triggers both the adhesion of leukocytes and migration of activated platelets into the endothelium by an increased permeability for plasma lipid components, such as low-density lipoprotein (LDL) [4, 19]. Monocytes and $\mathrm{T}$ cells bind to VCAM-1-expressing endothelial cells and migrate into the arterial tissue. The recruited monocytes then differentiate into macrophages and augment expression of many pattern-recognition receptors, including scavenger receptors $[20,21]$. The macrophages accumulate cholesterol via scavenger receptors and become foam cells. This leads to intimal fatty-streak lesions. During this time, there is a chronic inflammatory response to these modified lipids [4].

The inflammatory response is mediated by components of the innate immune system, including macrophages and dendritic cells $[22,23]$ and by components of the adaptive immune system, including $\mathrm{T}$ lymphocytes $[4,24]$. T cells become activated in response to antigen and contribute to disease progression by producing proinflammatory mediators, which further amplifies the inflammatory response. The continued cell accumulation and the subsequent apoptosis of plaque cells lead to the formation of a necrotic core and result in the progressive narrowing of the arterial lumen.

The pro- and anti-inflammatory mediators regulate the magnitude of the inflammatory response within the plaque as well as plaque stability and the propensity for thrombus formation by modulating apoptosis, collagen production, and smooth muscle cell content. In the later stages of atherogenesis, B cells and plasma cells also appear in the deeper layers of the plaque and in the adventitia [25]. Secretion of matrix proteases and cytokines by plaque cells can then trigger thinning of the fibrous cap and its disintegration with plaque erosion or rupture, leading to thrombus formation and vascular occlusion, which underlie coronary syndromes, myocardial infarction, and stroke.

\section{Th1 Immunity in Atherosclerosis}

It has been clearly shown that the adaptive immune system affects the development of atherosclerosis [22]. At present, Th1 cytokines are regarded as important proinflammatory regulators during atherogenesis. Most of the $\mathrm{T}$ cells in atherosclerotic plaques are Th1 cells. In apolipoprotein E-deficient (apoE ${ }^{-/-}$) or LDL receptor-deficient $\left(\mathrm{LDLR}^{-/-}\right)$mice in combination with both $\mathrm{T}$ and $\mathrm{B}$ cell deficiencies, there is a significant reduction in early atherosclerotic lesion development $[26,27]$. The principal Th1 cytokine, IFN- $\gamma$, is produced by most T cells in the human atherosclerotic plaque $[28,29]$. Moreover, adoptive transfer of $\mathrm{CD} 4+\mathrm{T}$ cells from apoE $\mathrm{E}^{-/-}$mice into apoE ${ }^{-/-}$severe combined immunodefiency mice enhances atherosclerosis [30]. The transplanted cells produced high levels of IFN- $\gamma$, suggesting a Th1-related proatherogenic effect. Atherosclerosis is attenuated in both IFN- $\gamma$ deficient and IFN- $\gamma \mathrm{R}$-deficient mice [31-33], and injections of recombinant IFN- $\gamma$ increase lesion size [34]. While IFN- $\gamma$ injections lead to a decrease in serum cholesterol, this effect does not protect against the proatherogenic effect of IFN- $\gamma$ [34].

IL-12 is the principal cytokine promoting Th1 development. IL-12 synergizes with IL-18 for full induction of IFN- $\gamma$. Recombinant IL-12 aggravates disease in apoE ${ }^{-/-}$ mice, concomitant with increased IFN- $\gamma$ expression in the aorta [35]. Indeed, apoE ${ }^{-/-}$IL-12p $40^{-/-}$mice exhibit reduced atherosclerotic plaque area [36]. $\mathrm{apoE}^{-/-}$mice 


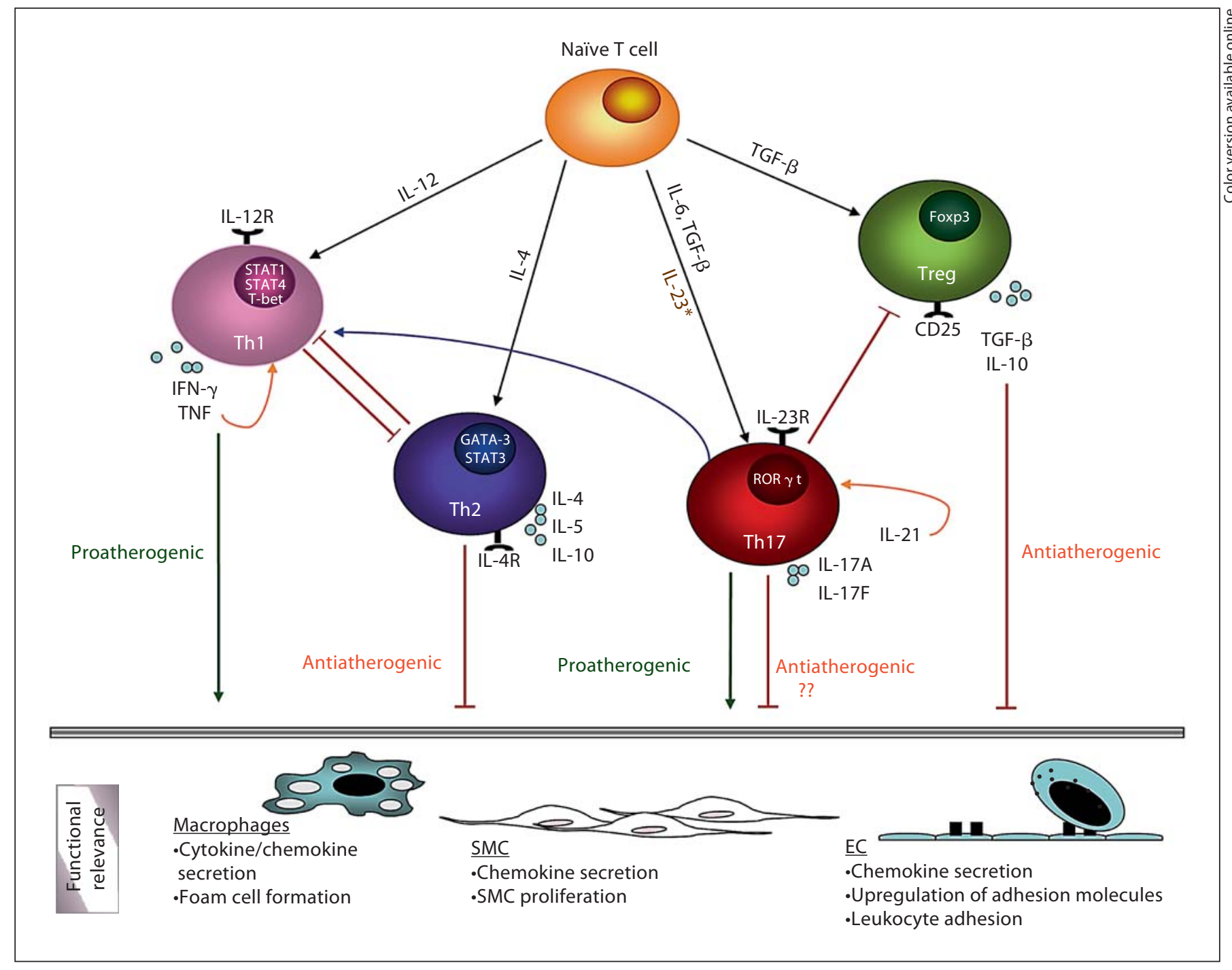

Fig. 1. Complex interactions of $\mathrm{CD} 4+\mathrm{T}$ cell subsets involved in atherosclerosis. $\mathrm{SMC}=\mathrm{Smooth}$ muscle cell; $\mathrm{EC}=$ endothelium cell. ${ }^{*}$ In mice, differentiation of Th17 cells is driven by TGF- $\beta$ together with IL-6. In humans, Th17 differentiation requires TGF- $\beta$ and IL-6, enhanced by IL-23, with IL-23 critically required for maintenance of the IL-17-secreting phenotype.

treated with plasmid DNA encoding for IL-18 binding protein [37] and apo: $\mathrm{E}^{-/-}$IL-18 $8^{-/-}$mice [38] exhibited reduced lesion development, whereas IL-18 treatment of apoE $^{-/-}$mice accelerated atherosclerosis development [39]. Thus, IL-18 was hypothesized to have proatherogenic effects.

Two major autoantigens, oxidized LDL and heat shock proteins (HSP), have been implicated in the pathogenesis of atherosclerosis [29, 40,41]. After challenge with HSP, plaque-derived T cells expressed Th1 functions, became cytotoxic, and induced tissue factor production in mac- rophages [41]. The results of the recent study by Matsuura et al. [42] also indicated that the systemic Th1-immune response against Hp-HSP60 induced by Helicobacter pylori infection in the gastric mucosa might promote atherosclerosis because elevated production of Th1-cytokines, such as IFN- $\gamma$ and IL-12, was observed as well as expression of T-bet mRNA (Th1-polarization marker) [42]. Overall, these results provide convincing elements to incriminate Th1-related responses in the promotion of atherosclerotic plaque development and progression (fig. 1). 


\section{Th2 Cells}

In contrast, Th 2 cells produce mostly IL- 4 , IL-5, and IL-10, and are associated with eosinophilic inflammatory responses to helminths, ticks, and allergens. The Th2 axis inhibits the formation and differentiation of Th1 cells and vice versa. IL-5 deficiency in $\mathrm{LDLR}^{-/-}$mice leads to enhanced lesion formation in a bone marrow transplantation model [43]. Thus, IL-5 acts in an antiatherogenic fashion by stimulating the production of protective antibodies. The Th2 cytokine profile in mouse models of atherosclerosis is associated with increased production of 'protective' antioxidized LDL antibodies [44]. Furthermore, splenectomy in cholesterolfed $\mathrm{apoE}^{-/-}$mice, which is associated with reduced levels of IgM and Th2-related IgG antioxidized LDL antibodies, increases atherosclerosis [45]. In addition, promoting Th2 responses in mice with mild hypercholesterolemia results in a reduction of early fatty-streak formation [46]. However, $\mathrm{LDLR}^{-/-}$mice reconstituted with IL-4-deficient bone marrow develop less severe atherosclerosis [47], particularly at the advanced stages of lesion progression [36]. This data indicate that IL-4 may be proatherogenic.

\section{Th1 and Th2: Yin and Yang}

The interplay between Th1 and Th2 cell types describes an attractive concept of yin and yang controlling the development of atherosclerosis $[48,49]$. On the other hand, IL-12, the prototypical Th1 skewing cytokine commonly produced by cells in the atherosclerotic lesion, can block the effects of the Th2 skewing cytokine, thymic stromal lymphopoietin protein. This protein has been shown to be produced by smooth muscle cells in the lung and, thus, it is possible that the arterial smooth muscle cells might also produce this Th2 skewing cytokine [50].

\section{T Regulatory Cells}

Recently, CD4+CD25+ regulatory T cells (Tregs) and Th17 cells have been described as two distinct subsets of Th1 and Th 2 cells. Tregs expressing the forkhead/winged helix transcription factor (Foxp3) have an anti-inflammatory role and maintain tolerance to self-components by contact-dependent suppression or releasing anti-inflammatory cytokines [IL-10 and transforming growth factor (TGF)- $\beta 1$ ]. It has been demonstrated that TGF- $\beta$ has an antiatherosclerotic effect by using TGF- $\beta$ neutralizing antibodies [51], genetic deficiency in TGF- $\beta$ [52], or soluble TGF- $\beta$ receptors [53] in apoE ${ }^{-/-}$mice. Reduction in atherosclerosis in $\mathrm{apoE}^{-/-}$mice has also been achieved through adoptive transfer of CD4+CD25+ Tregs [54, 55]. The protective role of IL-10 in [56] atherosclerosis has also been shown in C57BL6 mice, apoE ${ }^{-/-}$mice, and the $\mathrm{LDLR}^{-/-}$mouse model [57-60]. The balance between Th17 and Tregs may be important in the development/ prevention of inflammatory and autoimmune diseases [61] (fig. 1).

\section{Th17 Axis}

Recently a subset of CD4 T cells has been categorized into the Th17 lineage, which is distinct from the Th1 and Th2 lineages $[62,63]$. Th17 cells differentiate from naive CD $4+\mathrm{T}$ cells by TGF- $\beta 1$, and the inflammatory cytokine IL-6. IL-21 produced by Th17 cells promotes Th17 cell commitment in an autocrine manner, whereas IL-23 maintains and expands these cells in vivo. The transcription factors ROR $\gamma \mathrm{t}$ and ROR $\alpha$ can be induced by IL-6, IL-21, and IL-23 through Stat 3 alone with TGF$\beta 1$ [64-70]. Th17 cell development is controlled by transcription factors ROR $\gamma \mathrm{t}$ (human ortholog is RORC) and ROR $\alpha$. It has been reported that LPS-stimulated dendritic cells are potent inducers of Th17 development [71]. In addition to IL- 6 and TGF- $\beta 1$, inflammatory cytokines such as IL-1 and tumor necrosis factor (TNF) are contributors to murine Th17 differentiation. Although differentiation of Th17 cells in vitro can occur in the absence of IL-1, IL-1RI ${ }^{-/}$mice have impaired Th17 cell differentiation and reduced incidence of EAE associated with failure to induce autoantigen-specific Th17 cells [72]. It has been demonstrated that the activator protein 1 transcription factor Batf controls Th17 differentiation [73]. Batf $\left(^{--}\right)$mice have normal Th1 and Th2 differentiation, but show a defect in Th17 differentiation, and are resistant to experimental autoimmune encephalomyelitis. Batf( $\left(^{--}\right)$T cells fail to express ROR $\gamma \mathrm{t}$ and IL-21 [66-68, 70].

\section{Members of IL-17 Family Ligands}

IL-17 and its related proteins have been cloned, grouped, and designated as the IL-17 cytokine family (IL$17 \mathrm{~A}-\mathrm{F})[10,63]$. IL-17, which is primarily produced by 
Th17 cells, coordinates local tissue inflammation via induced release of proinflammatory cytokines and neutrophil-mobilizing chemokines from various cell types, including epithelial cells [9]. IL-17 is involved in the pathogenesis of several autoimmune diseases such as rheumatoid arthritis, inflammatory bowel disease, and asthma. This cytokine may also contribute to host defense during microbial infections of the lung [74]. However, IL-23-mediated IL-17A has also been associated with a protective role in $\mathrm{T}$ cell-mediated intestinal inflammation [8]. Therefore, its effect on the surrounding tissues and local immune system may be environmentspecific and probably depends on the overall immunological state at the time in specific disease models.

Thus far, six IL-17 family ligands (IL-17A through IL17F) have been identified. All members of the IL-17 family share a similar protein structure characterized by four highly conserved cysteine residues, but they have no sequence similarity to any other known cytokines $[75,76]$. IL-17E, more commonly called IL-25, has different biologic functions, but shares structural features with other IL-17 family members [77, 78]. IL-17A and IL-17F (which are 55\% homologous) are both produced by Th17 cells and are the most characterized to date. The IL-17A and IL-17F genes are located adjacent to each other, suggesting the genes encoding IL-17A and IL-17F are the result of a duplication event. Moreover, the IL$17 \mathrm{~A}$ and IL-17F transcription factor ROR $\gamma \mathrm{t}$ exhibits a similar expression pattern [79-81]. Both IL-17A and IL$17 \mathrm{~F}$ act as homodimers, but an IL-17A/F heterodimer has been described recently [82-84]. Since IL-17A and IL-17F share common features, they may have a similar regulatory effect. They also induce common transducing pathways through a complex composed of the IL17RA and IL-17RC receptors $[85,86]$. Unlike IL-17A and IL-17F, IL-17E is involved in promoting Th2 immune responses [63]. Furthermore, IL-17E is known to play an important role during allergic airway hyper-reactivity reactions [87].

The IL-17 receptor (IL-17R) subfamily includes IL17RA, IL-17RB, IL-17RC, IL-17RD, and IL-17RE reviewed in $[10,13]$. IL-17RD is also known to have a similar expression as fibroblast growth factor receptor (SEF), as it was initially described as having the same expression pattern as the fibroblast growth factor receptor during zebrafish development [19]. The IL-17A receptor is ubiquitously expressed and the cytokine leads to pleiotropic activities, including induction of TNF- $\alpha$, IL-1, and MCP1 , as well as adhesion molecules like intercellular adhesion molecule 1 (ICAM-1) [88].

IL-17 and Atherosclerosis

\section{IL-17/Th17 and Inflammation and Atherosclerosis}

Th17 cells, characterized by production of the inflammatory cytokine IL-17, were shown to promote chronic inflammatory as well as autoimmune diseases, including experimental models of arthritis, autoimmune encephalitis, and colitis $[89,90]$. While the role of IL-17 has been studied extensively in several inflammatory and autoimmune disorders, its role in atherosclerosis development remains controversial. Previously, only indirect clues existed for the potential role of IL-17 in atherogenesis. LDLR/IL- 6 double KO mice, which exhibit a decrease of IL-17 levels [91], were found to have a modest reduction in atherosclerotic lesion development, suggesting a potential role for Th17 in the promotion of atherogenesis. Most importantly, a recent study demonstrated the concomitant presence of IL-17 and IFN- $\gamma$ in clinical specimens of coronary atherosclerosis by showing the presence of IL-17/IFN- $\gamma$ dual-producing T cells within coronary plaques and a synergistic effect of IL-17 and IFN- $\gamma$ on elicitation of proinflammatory cytokine and chemokine production by cultured human vascular smooth muscle cells [92]. Another study reported that patients with acute coronary syndrome have significantly increased peripheral Th17 cell numbers, circulating Th17related cytokine levels (IL-17, IL-6, and IL-23), increased expression of the transcription factor (ROR $\gamma \mathrm{t}$ ), and a decrease in Treg numbers. Additionally, Treg-related cytokines (IL-10 and TGF- $\beta 1$ ), and the transcription factor Foxp3 were all reduced as compared with patients with stable angina and controls [93].

In contrast to these studies, Taleb et al. [14] recently published loss of suppressor of cytokine signaling-3 (SOCS-3) in mouse T cells increases both IL-17A and IL10 production, inducing an anti-inflammatory macrophage phenotype which results in a reduction in lesion development and vascular inflammation. This suggests that IL-17 may have a protective role in atherogenesis. However, it was unclear as to whether IL-10 or IL-17 was leading to the suppressor phenotype, as IL-10 is a very potent regulatory cytokine which is atheroprotective. Additionally, these investigators have also shown that in vivo administration of rIL-17 to $\mathrm{LDLR}^{-/}$mice resulted in reduced endothelial VCAM-1 expression, as well as reduced vascular $\mathrm{T}$ cell infiltration and atherosclerotic lesion development [14]. These investigators concluded that endogenous expression of SOCS3 in T cells interrupts a major regulatory pathway in atherosclerosis through inhibition of IL-17 production and that IL-17 functions as an atheroprotective cytokine [14].

J Innate Immun 2010;2:325-333 
Interestingly, several more recent studies by various investigators have now shown additional, and in some cases more direct, evidence for the proatherogenic role of IL-17. Xie et al. [94] demonstrated that apoE $\mathrm{E}^{-/-}$mice express a significant increase in Th17-related cytokines (IL17 and IL-6) and transcription factor (ROR yt) levels and a concomitant decrease in Treg numbers, Treg-related cytokines (TGF- $\beta 1$ ), and transcription factor (Foxp3) levels as compared with age-matched C57BL/6J mice. This indicates that a Th17/Treg functional imbalance exists during atherogenesis in $\mathrm{apoE}^{-/-}$mice [94]. Another recent study found that different IL-17 family members (IL-17A, IL-17F, and IL-17E) are expressed in human atherosclerotic lesions [95]. The major source of proinflammatory cytokines, IL-17A and IL-17F, were not T cells (Th17), but mast cells and neutrophils [95]. Furthermore, the antiinflammatory cytokine IL-17E was found to be expressed in normal and atherosclerotic vessels, and might play a role in regulating inflammatory processes in the vessel wall [95]. In another recent study investigating the apoE/ IL18 double KO mice, investigators have shown that the exacerbated atherosclerotic lesion formation correlated with increased Th17 cells, IL-23-producing vascular smooth muscle cells and macrophages, and a thin fibrous cap in lesions, a morphology indicative of unstable plaques prone to rupture [96].

The most direct evidence of the proatherogenic role of IL-17 comes from four very recent studies. van Es et al. [15] conduced bone marrow chimera studies and transplanted irradiated LDLR-deficient recipient mice with IL-17R-deficient bone marrow. They observed that Western-type diet-induced atherosclerotic lesions were reduced by $46 \%$ in the aortic root and plaque in the recipient mice.

Erbel et al. [16] administered in vivo IL-17A-blocking antibody in $a \mathrm{poE}^{-/-}$mice, and found that functional blockade of IL-17A reduced atherosclerotic lesion development and decreased plaque vulnerability, cellular infiltration, and tissue activation in apoE-deficient mice. They concluded that the involvement of IL-17 in proatherogenesis appears to be via proinflammatory changes at multiple levels such as cell adhesion, extravasation, cell activation, $\mathrm{T}$ cell (co)stimulation/proliferation, and $\mathrm{Ag}$ presentation in the inflammatory cascade of atherosclerosis [16]. A limitation of this study is that blocking IL17A will not prevent the formation of Th17 cells, or other IL-17 producing cell types, which may also have effects aside from IL-17A production [63, 97, 98].

In the most recent Keystone Symposia (Advances in Molecular Mechanisms of Atherosclerosis, February
2010), Smith et al. [99] showed that IL-17A+ T cells were significantly increased in the aortas and surrounding adventitia, spleen, and lamina propria of aged $\mathrm{apoE}^{-/-}$mice compared to the control C57Bl6 mice. The IL-17A+ cells were characterized as $\mathrm{CD} 45+\mathrm{CD} 3+\mathrm{T}$ cells and were predominantly Th17 and $\gamma \delta+\mathrm{T}$ cells. Blockade of IL-17A in apoE $\mathrm{E}^{-/-}$mice using adenovirus-produced soluble IL-17Rreduced plaque in treated $\mathrm{apoE}^{-/-}$mice fed a Western diet resulted in significant reduction of atherosclerotic lesions [99].

Nagarajan et al. [100] also demonstrated that apoE/ Fc $\gamma$ chain double KO mice had a $50 \%$ reduction of aortic lesion compared to apoE ${ }^{-/-}$mice, and the double $\mathrm{KO}$ mice had high IFN- $\gamma$ and IL-17, but lower IL-10 and TGF- $\beta$ expression. In addition to all these studies, we have shown in the same Keystone Meetings that IL-17A ${ }^{-/-}$mice (on a C57/Bl6 background) develop significantly smaller atherosclerotic lesion size and less lipid deposition in the aorta and aortic sinus following 12 weeks of a high-fat diet (cholate) compared to wild-type C57Bl/6 mice [101].

\section{Concluding Remarks}

Although the precise role of IL-17 in atherosclerosis remains controversial, recent studies have begun to provide more direct evidence that IL-17 seems to be predominantly proatherogenic. Nevertheless, IL-17 clearly has pleiotropic and environment-specific protective and regulatory functions. Hence, the role of IL-17 in various stages of lesion development are still unknown and probably complex. It will therefore be important to further investigate this intersection between more traditional immunology and vascular biology, and to address and resolve questions raised by conflicting studies. Additionally, the effects of other isoforms of IL-17 (e.g. IL-17F or IL-17E) have not even begun to be investigated. This research area will continue to provide many opportunities for investigations that will significantly expand our understanding of how specific immune cells and general immune paradigms, such as Th1, Th2, and Th17, influence the development of atheroma and its clinical sequelae.

\section{Acknowledgements}

The authors are supported by grants from NIH HL66436 and AI 067995 to M.A. and AHA 09BGIA2060145 to S.C. 


\section{References}

-1 Hansson GK, Libby P, Schonbeck U, Yan ZQ: Innate and adaptive immunity in the pathogenesis of atherosclerosis. Circ Res 2002;91: 281-291.

-2 van der Wal AC, Das PK, Bentz van de Berg $\mathrm{D}$, van der Loos CM, Becker AE: Atherosclerotic lesions in humans. In situ immunophenotypic analysis suggesting an immune mediated response. Lab Invest 1989;61:166-170.

3 Kovanen PT, Kaartinen M, Paavonen T: Infiltrates of activated mast cells at the site of coronary atheromatous erosion or rupture in myocardial infarction. Circulation 1995;92: 1084-1088.

$\checkmark 4$ Hansson GK: Inflammation, atherosclerosis, and coronary artery disease. N Engl J Med 2005;352:1685-1695.

$\checkmark 5$ Vanderlaan PA, Reardon CA: Thematic review series: the immune system and atherogenesis. The unusual suspects: an overview of the minor leukocyte populations in atherosclerosis. J Lipid Res 2005;46:829-838.

6 Wick G, Knoflach M, Xu Q: Autoimmune and inflammatory mechanisms in atherosclerosis. Annu Rev Immunol 2004;22:361403.

7 Coffman RL: Origins of the $\mathrm{t}(\mathrm{h}) 1-\mathrm{t}(\mathrm{h}) 2 \mathrm{mod}-$ el: a personal perspective. Nat Immunol 2006;7:539-541.

$\checkmark 8$ O'Connor W Jr, Kamanaka M, Booth CJ, Town T, Nakae S, Iwakura Y, Kolls JK, Flavell RA: A protective function for interleukin $17 \mathrm{~A}$ in $\mathrm{T}$ cell-mediated intestinal inflamma tion. Nat Immunol 2009;10:603-609.

$\checkmark 9$ Kolls JK, Linden A: Interleukin-17 family members and inflammation. Immunity 2004;21:467-476.

-10 Moseley TA, Haudenschild DR, Rose L, Reddi AH: Interleukin-17 family and IL-17 receptors. Cytokine Growth Factor Rev 2003; 14:155-174.

-11 Niess JH, Leithauser F, Adler G, Reimann J: Commensal gut flora drives the expansion of proinflammatory CD4 T cells in the colonic lamina propria under normal and inflammatory conditions. J Immunol 2008;180: 559-568.

-12 Ivanov, II, Atarashi K, Manel N, Brodie EL, Shima T, Karaoz U, Wei D, Goldfarb KC, Santee CA, Lynch SV, Tanoue T, Imaoka A, Itoh K, Takeda K, Umesaki Y, Honda K, Littman DR: Induction of intestinal Th17 cells by segmented filamentous bacteria. Cell 2009;139:485-498.

$>13$ Kullberg MC, Jankovic D, Feng CG, Hue S, Gorelick PL, McKenzie BS, Cua DJ, Powrie F, Cheever AW, Maloy KJ, Sher A: IL-23 plays a key role in Helicobacter hepaticus-induced T cell-dependent colitis. J Exp Med 2006;203: 2485-2494.
14 Taleb S, Romain M, Ramkhelawon B, Uyttenhove C, Pasterkamp G, Herbin O, Esposito B, Perez N, Yasukawa H, Van Snick J, Yoshimura A, Tedgui A, Mallat Z: Loss of SOCS3 expression in $T$ cells reveals a regulatory role for interleukin-17 in atherosclerosis. J Exp Med 2009;206:2067-2077.

15 van Es T, van Puijvelde $\mathrm{GH}$, Ramos $\mathrm{OH}$ Segers FM, Joosten LA, van den Berg WB, Michon IM, de Vos P, van Berkel TJ, Kuiper J: Attenuated atherosclerosis upon IL-17R signaling disruption in LDLr deficient mice. Biochem Biophys Res Commun 2009;388: 261-265.

16 Erbel C, Chen L, Bea F, Wangler S, Celik S, Lasitschka F, Wang Y, Bockler D, Katus HA, Dengler TJ: Inhibition of IL-17A attenuates atherosclerotic lesion development in apoEdeficient mice. J Immunol 2009;183:81678175.

17 Cybulsky MI, Gimbrone MA Jr: Endothelial expression of a mononuclear leukocyte adhesion molecule during atherogenesis. Science 1991;251:788-791.

18 Nakashima Y, Raines EW, Plump AS, Breslow JL, Ross R: Upregulation of VCAM-1 and ICAM-1 at atherosclerosis-prone sites on the endothelium in the ApoE-deficient mouse. Arterioscler Thromb Vasc Biol 1998; 18:842851.

19 Ross R: Atherosclerosis - an inflammator disease. N Engl J Med 1999;340:115-126.

20 Smith JD, Trogan E, Ginsberg M, Grigaux C, Tian J, Miyata M: Decreased atherosclerosis in mice deficient in both macrophage colony-stimulating factor (op) and apolipoprotein E. Proc Natl Acad Sci USA 1995;92: 8264-8268.

21 Edfeldt K, Swedenborg J, Hansson GK, Yan ZQ: Expression of toll-like receptors in human atherosclerotic lesions: a possible pathway for plaque activation. Circulation 2002; 105:1158-1161.

22 Binder CJ, Chang MK, Shaw PX, Miller YI, Hartvigsen K, Dewan A, Witztum JL: Innate and acquired immunity in atherogenesis. Nat Med 2002;8:1218-1226.

23 Yan ZQ, Hansson GK: Innate immunity, macrophage activation, and atherosclerosis Immunol Rev 2007;219:187-203.

24 Hansson GK: Immune mechanisms in atherosclerosis. Arterioscler Thromb Vasc Biol 2001;21:1876-1890.

25 Houtkamp MA, van Der Wal AC, de Boer OJ, van Der Loos CM, de Boer PA, Moorman AF, Becker AE: Interleukin-15 expression in atherosclerotic plaques: An alternative pathway for T-cell activation in atherosclerosis? Arterioscler Thromb Vasc Biol 2001;21:12081213.

-26 Dansky HM, Charlton SA, Harper MM, Smith JD: T and B lymphocytes play a minor role in atherosclerotic plaque formation in the apolipoprotein E-deficient mouse. Proc Natl Acad Sci USA 1997;94:4642-4646.
27 Daugherty A, Pure E, Delfel-Butteiger D, Chen S, Leferovich J, Roselaar SE, Rader DJ: The effects of total lymphocyte deficiency on the extent of atherosclerosis in apolipoprotein $\mathrm{E}^{-/-}$mice. J Clin Invest 1997;100:15751580.

$>28$ Hansson GK, Holm J, Jonasson L: Detection of activated $\mathrm{T}$ lymphocytes in the human atherosclerotic plaque. Am J Pathol 1989; 135:169-175.

29 Stemme S, Faber B, Holm J, Wiklund O, Witztum JL, Hansson GK: T lymphocytes from human atherosclerotic plaques recognize oxidized low density lipoprotein. Proc Natl Acad Sci USA 1995;92:3893-3897.

30 Zhou X, Nicoletti A, Elhage R, Hansson GK: Transfer of CD4(+) T cells aggravates atherosclerosis in immunodeficient apolipoprotein E knockout mice. Circulation 2000;102: 2919-2922.

-31 Buono C, Come CE, Stavrakis G, Maguire GF, Connelly PW, Lichtman AH: Influence of interferon-gamma on the extent and phenotype of diet-induced atherosclerosis in the LDLr-deficient mouse. Arterioscler Thromb Vasc Biol 2003;23:454-460.

32 Gupta S, Pablo AM, Jiang X, Wang N, Tall AR, Schindler C: IFN-gamma potentiates atherosclerosis in ApoE knock-out mice. J Clin Invest 1997;99:2752-2761.

33 Whitman SC, Ravisankar P, Daugherty A: IFN-gamma deficiency exerts gender-specific effects on atherogenesis in apolipoprotein $\mathrm{E}^{-/-}$mice. J Interferon Cytokine Res 2002;22:661-670

34 Whitman SC, Ravisankar P, Elam H, Daugherty A: Exogenous interferon-gamma enhances atherosclerosis in apolipoprotein $\mathrm{E}^{-/-}$ mice. Am J Pathol 2000;157:1819-1824.

35 Lee TS, Yen HC, Pan CC, Chau LY: The role of interleukin 12 in the development of atherosclerosis in ApoE-deficient mice. Arterioscler Thromb Vasc Biol 1999;19:734-742.

36 Davenport P, Tipping PG: The role of interleukin-4 and interleukin-12 in the progression of atherosclerosis in apolipoprotein Edeficient mice. Am J Pathol 2003;163: 1117-1125.

>37 Mallat Z, Corbaz A, Scoazec A, Graber P, Alouani S, Esposito B, Humbert Y, Chvatchko Y, Tedgui A: Interleukin-18/interleukin-18 binding protein signaling modulates atherosclerotic lesion development and stability. Circ Res 2001;89:E41-E45.

38 Elhage R, Jawien J, Rudling M, Ljunggren HG, Takeda K, Akira S, Bayard F, Hansson GK: Reduced atherosclerosis in interleukin-18 deficient apolipoprotein E-knockout mice. Cardiovasc Res 2003;59:234-240.

-39 Whitman SC, Ravisankar P, Daugherty A: Interleukin-18 enhances atherosclerosis in apolipoprotein E(-/-) mice through release of interferon-gamma. Circ Res 2002;90:E34E38. 
-40 Xu Q, Kleindienst R, Waitz W, Dietrich H, Wick G: Increased expression of heat shock protein 65 coincides with a population of infiltrating $\mathrm{T}$ lymphocytes in atherosclerotic lesions of rabbits specifically responding to heat shock protein 65. J Clin Invest 1993;91: 2693-2702.

-41 Benagiano M, D’Elios MM, Amedei A, Azzurri A, van der Zee R, Ciervo A, Rombola G, Romagnani S, Cassone A, Del Prete G: Human $60-\mathrm{kDa}$ heat shock protein is a target autoantigen of $\mathrm{T}$ cells derived from atherosclerotic plaques. J Immunol 2005; 174:65096517.

-42 Matsuura E, Kobayashi K, Matsunami Y, Shen L, Quan N, Makarova M, Suchkov SV, Ayada K, Oguma K, Lopez LR: Autoimmunity, infectious immunity, and atherosclerosis. J Clin Immunol 2009;29:714-721.

-43 Binder CJ, Hartvigsen K, Chang MK, Miller M, Broide D, Palinski W, Curtiss LK, Corr M, Witztum JL: IL-5 links adaptive and natural immunity specific for epitopes of oxidized LDL and protects from atherosclerosis. J Clin Invest 2004;114:427-437.

44 Zhou X, Paulsson G, Stemme S, Hansson GK: Hypercholesterolemia is associated with a T helper (Th) 1/Th2 switch of the autoimmune response in atherosclerotic apo Eknockout mice. J Clin Invest 1998;101:17171725 .

45 Caligiuri G, Nicoletti A, Poirier B, Hansson GK: Protective immunity against atherosclerosis carried by B cells of hypercholesterolemic mice. J Clin Invest 2002;109:745-753.

46 Huber SA, Sakkinen P, David C, Newell MK, Tracy RP: T helper-cell phenotype regulates atherosclerosis in mice under conditions of mild hypercholesterolemia. Circulation 2001;103:2610-2616.

47 King VL, Szilvassy SJ, Daugherty A: Interleukin-4 deficiency decreases atherosclerotic lesion formation in a site-specific manner in female LDL receptor-/- mice. Arterioscler Thromb Vasc Biol 2002;22:456-461.

48 Daugherty A, Rateri DL: T lymphocytes in atherosclerosis: the yin-yang of Th1 and Th2 influence on lesion formation. Circ Res 2002; 90:1039-1040.

49 Abbas AK, Murphy KM, Sher A: Functional diversity of helper T lymphocytes. Nature 1996;383:787-793.

-50 He R, Oyoshi MK, Garibyan L, Kumar L, Ziegler SF, Geha RS: TSLP acts on infiltrating effector T cells to drive allergic skin inflammation. Proc Natl Acad Sci USA 2008; 105:11875-11880.

51 Mallat Z, Gojova A, Marchiol-Fournigault C, Esposito B, Kamate C, Merval R, Fradelizi D, Tedgui A: Inhibition of transforming growth factor-beta signaling accelerates atherosclerosis and induces an unstable plaque phenotype in mice. Circ Res 2001;89:930934.
2 Grainger DJ, Mosedale DE, Metcalfe JC, Bottinger EP: Dietary fat and reduced levels of TGFbetal act synergistically to promote activation of the vascular endothelium and formation of lipid lesions. J Cell Sci 2000;113. 2355-2361.

53 Lutgens E, Gijbels M, Smook M, Heeringa P, Gotwals P, Koteliansky VE, Daemen MJ: Transforming growth factor-beta mediates balance between inflammation and fibrosis during plaque progression. Arterioscler Thromb Vasc Biol 2002;22:975-982.

54 Mor A, Planer D, Luboshits G, Afek A, Metzger S, Chajek-Shaul T, Keren G, George J: Role of naturally occurring CD4+ CD25+ regulatory $\mathrm{T}$ cells in experimental atherosclerosis. Arterioscler Thromb Vasc Biol 2007;27:893-900.

55 Ait-Oufella H, Salomon BL, Potteaux S, Robertson AK, Gourdy P, Zoll J, Merval R, Esposito B, Cohen JL, Fisson S, Flavell RA, Hansson GK, Klatzmann D, Tedgui A, Mallat Z: Natural regulatory $T$ cells control the development of atherosclerosis in mice. Nat Med 2006;12:178-180.

56 Sakaguchi S, Ono M, Setoguchi R, Yagi H, Hori S, Fehervari Z, Shimizu J, Takahashi T, Nomura T: Foxp3+ CD25+ CD4+ natural regulatory $\mathrm{T}$ cells in dominant self-tolerance and autoimmune disease. Immunol Rev 2006;212:8-27.

57 Mallat Z, Besnard S, Duriez M, Deleuze V, Emmanuel F, Bureau MF, Soubrier F, Esposito B, Duez H, Fievet C, Staels B, Duverger N, Scherman D, Tedgui A: Protective role of interleukin-10 in atherosclerosis. Circ Res 1999;85:e17-e24.

58 Pinderski Oslund LJ, Hedrick CC, Olvera T, Hagenbaugh A, Territo M, Berliner JA, Fyfe AI: Interleukin-10 blocks atherosclerotic events in vitro and in vivo. Arterioscler Thromb Vasc Biol 1999; 19:2847-2853.

59 Caligiuri G, Rudling M, Ollivier V, Jacob MP, Michel JB, Hansson GK, Nicoletti A: Interleukin-10 deficiency increases atherosclerosis, thrombosis, and low-density lipoproteins in apolipoprotein e knockout mice. Mol Med 2003;9:10-17.

60 Von Der Thusen JH, Kuiper J, Fekkes ML, De Vos P, Van Berkel TJ, Biessen EA: Attenuation of atherogenesis by systemic and local adenovirus-mediated gene transfer of interleukin-10 in LDLr-/- mice. FASEB J 2001;15: 2730-2732.

61 Homey B: After Th1/Th2 now comes Treg/ Th17:Significance of T helper cells in immune response organization (in German). Hautarzt 2006;57:730-732.

62 Stockinger B, Veldhoen M: Differentiation and function of Th17 T cells. Curr Opin Immunol 2007;19:281-286.

63 Weaver CT, Hatton RD, Mangan PR, Harrington LE: IL-17 family cytokines and the expanding diversity of effector $\mathrm{T}$ cell lineages. Annu Rev Immunol 2007;25:821-852.
64 Chen Z, Laurence A, Kanno Y, Pacher-Zavisin M, Zhu BM, Tato C, Yoshimura A, Hennighausen L, O'Shea JJ: Selective regulatory function of SOCS3 in the formation of IL-17secreting T cells. Proc Natl Acad Sci USA 2006; 103:8137-8142.

65 Dong C: Th17 cells in development: an updated view of their molecular identity and genetic programming. Nat Rev Immunol 2008;8:337-348.

66 Korn T, Bettelli E, Gao W, Awasthi A, Jager A, Strom TB, Oukka M, Kuchroo VK: IL-21 initiates an alternative pathway to induce proinflammatory T(h)17 cells. Nature 2007; 448:484-487.

-67 Nurieva R, Yang XO, Martinez G, Zhang Y, Panopoulos AD, Ma L, Schluns K, Tian Q, Watowich SS, Jetten AM, Dong C: Essential autocrine regulation by IL-21 in the generation of inflammatory T cells. Nature 2007; 448:480-483.

68 Wei L, Laurence A, Elias KM, O’Shea JJ: IL21 is produced by Th17 cells and drives IL-17 production in a STAT3-dependent manner. J Biol Chem 2007;282:34605-34610.

69 Yang L, Anderson DE, Baecher-Allan C, Hastings WD, Bettelli E, Oukka M, Kuchroo VK, Hafler DA: IL-21 and TGF-beta are required for differentiation of human $\mathrm{T}(\mathrm{h}) 17$ cells. Nature 2008;454:350-352.

70 Zhou L, Ivanov, II, Spolski R, Min R, Shenderov K, Egawa T, Levy DE, Leonard WJ, Littman DR: IL-6 programs T(h)-17 cell differentiation by promoting sequential engagement of the IL-21 and IL-23 pathways. Nat Immunol 2007;8:967-974.

71 Veldhoen M, Hocking RJ, Atkins CJ, Locksley RM, Stockinger B: TGFbeta in the context of an inflammatory cytokine milieu supports de novo differentiation of IL-17producing T cells. Immunity 2006;24:179189.

72 Sutton C, Brereton C, Keogh B, Mills KH, Lavelle EC: A crucial role for interleukin (IL)-1 in the induction of IL-17-producing T cells that mediate autoimmune encephalomyelitis. J Exp Med 2006;203:1685-1691.

73 Schraml BU, Hildner K, Ise W, Lee WL, Smith WA, Solomon B, Sahota G, Sim J, Mukasa R, Cemerski S, Hatton RD, Stormo GD, Weaver CT, Russell JH, Murphy TL, Murphy KM: The AP-1 transcription factor Batf controls $\mathrm{T}(\mathrm{H}) 17$ differentiation. Nature 2009; 460:405-409.

74 Tesmer LA, Lundy SK, Sarkar S, Fox DA: Th17 cells in human disease. Immunol Rev 2008;223:87-113.

75 Huang SH, Frydas S, Kempuraj D, Barbacane RC, Grilli A, Boucher W, Letourneau R, Madhappan B, Papadopoulou N, Verna N, De Lutiis MA, Iezzi T, Riccioni G, Theoharides TC, Conti P: Interleukin-17 and the interleukin-17 family member network. Allergy Asthma Proc 2004;25:17-21. 
-76 Gaffen SL, Kramer JM, Yu JJ, Shen F: The IL17 cytokine family. Vitam Horm 2006;74: 255-282.

-77 Lee J, Ho WH, Maruoka M, Corpuz RT, Baldwin DT, Foster JS, Goddard AD, Yansura DG, Vandlen RL, Wood WI, Gurney AL: IL-17E, a novel proinflammatory ligand for the IL-17 receptor homolog IL-17Rh1. J Biol Chem 2001;276:1660-1664.

-78 Fort MM, Cheung J, Yen D, Li J, Zurawski SM, Lo S, Menon S, Clifford T, Hunte B, Lesley R, Muchamuel T, Hurst SD, Zurawski G, Leach MW, Gorman DM, Rennick DM: IL25 induces IL-4, IL-5, and IL-13 and Th2-associated pathologies in vivo. Immunity 2001; 15:985-995.

-79 Ivanov II, McKenzie BS, Zhou L, Tadokoro CE, Lepelley A, Lafaille JJ, Cua DJ, Littman DR: The orphan nuclear receptor RORgammat directs the differentiation program of proinflammatory IL-17+ T helper cells. Cell 2006;126:1121-1133.

80 Langrish CL, Chen Y, Blumenschein WM, Mattson J, Basham B, Sedgwick JD, McClanahan T, Kastelein RA, Cua DJ: IL-23 drives a pathogenic $\mathrm{T}$ cell population that induces autoimmune inflammation. J Exp Med 2005;201:233-240.

-81 Harrington LE, Hatton RD, Mangan PR, Turner H, Murphy TL, Murphy KM, Weaver CT: Interleukin 17-producing CD4+ effector $\mathrm{T}$ cells develop via a lineage distinct from the T helper type 1 and 2 lineages. Nat Immunol 2005;6:1123-1132.

\$2 Liang SC, Long AJ, Bennett F, Whitters MJ, Karim R, Collins M, Goldman SJ, DunussiJoannopoulos K, Williams CM, Wright JF, Fouser LA: An IL-17F/A heterodimer protein is produced by mouse Th17 cells and induces airway neutrophil recruitment. J Immunol 2007; 179:7791-7799.

83 Wright JF, Guo Y, Quazi A, Luxenberg DP, Bennett F, Ross JF, Qiu Y, Whitters MJ, Tomkinson KN, Dunussi-Joannopoulos K, Carreno BM, Collins M, Wolfman NM: Identification of an interleukin 17F/17A heterodimer in activated human CD4+ T cells. J Biol Chem 2007;282:13447-13455.
84 Chang SH, Dong C: A novel heterodimeric cytokine consisting of IL-17 and IL-17F regulates inflammatory responses. Cell Res 2007; 17:435-440.

85 Toy D, Kugler D, Wolfson M, Vanden Bos T, Gurgel J, Derry J, Tocker J, Peschon J: Cutting edge: interleukin 17 signals through a heteromeric receptor complex. J Immunol 2006;177:36-39.

86 Mangan PR, Harrington LE, O’Quinn DB, Helms WS, Bullard DC, Elson CO, Hatton RD, Wahl SM, Schoeb TR, Weaver CT: Transforming growth factor-beta induces development of the $\mathrm{T}(\mathrm{h}) 17$ lineage. Nature 2006;441:231-234.

87 Tamachi T, Maezawa Y, Ikeda K, Kagami S, Hatano M, Seto Y, Suto A, Suzuki K, Watanabe N, Saito Y, Tokuhisa T, Iwamoto I, Nakajima H: IL-25 enhances allergic airway inflammation by amplifying a Th2 celldependent pathway in mice. J Allergy Clin Immunol 2006;118:606-614.

88 Jovanovic DV, Di Battista JA, Martel-Pelletier J, Jolicoeur FC, He Y, Zhang M, Mineau F, Pelletier JP: IL-17 stimulates the production and expression of proinflammatory cytokines, IL-beta and TNF-alpha, by human macrophages. J Immunol 1998;160:35133521.

89 Ouyang W, Kolls JK, Zheng Y: The biological functions of T helper 17 cell effector cytokines in inflammation. Immunity 2008;28: 454-467.

90 Dong C: Diversification of T-helper-cell lineages: finding the family root of IL-17-producing cells. Nat Rev Immunol 2006;6:329333.

91 Song L, Schindler C: IL- 6 and the acute phase response in murine atherosclerosis. Atherosclerosis 2004;177:43-51.

-92 Eid RE, Rao DA, Zhou J, Lo SF, Ranjbaran H, Gallo A, Sokol SI, Pfau S, Pober JS, Tellides G: Interleukin-17 and interferon-gamma are produced concomitantly by human coronary artery-infiltrating $\mathrm{T}$ cells and act synergistically on vascular smooth muscle cells. Circulation 2009;119:1424-1432.

$\checkmark 93$ Cheng X, Yu X, Ding YJ, Fu QQ, Xie JJ, Tang TT, Yao R, Chen Y, Liao YH: The Th17/Treg imbalance in patients with acute coronary syndrome. Clin Immunol 2008;127:89-97.
94 Xie JJ, Wang J, Tang TT, Chen J, Gao XL, Yuan J, Zhou ZH, Liao MY, Yao R, Yu X, Wang D, Cheng Y, Liao YH, Cheng X: The Th17/Treg functional imbalance during atherogenesis in ApoE(-/-) mice. Cytokine;49:185-193.

$\checkmark 95$ de Boer OJ, van der Meer JJ, Teeling P, van der Loos CM, Idu MM, van Maldegem F, Aten J, van der Wal AC: Differential expression of interleukin-17 family cytokines in intact and complicated human atherosclerotic plaques. J Pathol 2009;220:499-508.

$\checkmark 96$ Pejnovic N, Vratimos A, Lee SH, Popadic D, Takeda K, Akira S, Chan WL: Increased atherosclerotic lesions and Th17 in interleukin-18 deficient apolipoprotein Eknockout mice fed high-fat diet. Mol Immunol 2009;47:37-45.

$\checkmark 97$ Smith E, Stark MA, Zarbock A, Burcin TL, Bruce AC, Vaswani D, Foley P, Ley K: Il-17a inhibits the expansion of IL-17A-producing $\mathrm{T}$ cells in mice through 'short-loop' inhibition via IL-17 receptor. J Immunol 2008; 181:1357-1364.

98 Yang Y, Weiner J, Liu Y, Smith AJ, Huss DJ, Winger R, Peng H, Cravens PD, Racke MK, Lovett-Racke AE: T-bet is essential for encephalitogenicity of both Th1 and Th17 cells. J Exp Med 2009;206:1549-1564.

99 Smith E, Prasad KMR, Butcher M, Dobrian A, Kolls JK, Ley K, Galkina E: Blockade of IL-17A results in reduced atherosclerosis in apoE-deficient mice. Circulation 2010;121: 1746-1755.

100 Nagarajan S: Fcgamma chain deficiency on hematopoietic cells ameliorates atherosclerosis in apoE-knockout mice by blocking Th17 responses. Keystone Symposia Advances in Molecular Mechanisms of Atherosclerosis, Banff, 2010, pp 88.

101 Chen S, Shimada K, Crother T, Zhang W, Huang G, Arditi M: The role of nod/rip2 signaling and IL-17 in chlamydia pneumoniae (cpn) -mediated acceleration of atherosclerosis in hypercholesterolemic mice. Keystone Symposia Advances in Molecular Mechanisms of Atherosclerosis, Banff, 2010, pp 76 